\title{
Size-structured migration and feeding patterns in the banded puffer fish Colomesus psittacus (Tetraodontidae) from north Brazilian mangrove creeks
}

\author{
Tommaso Giarrizzo $^{1, *}$, Uwe Krumme ${ }^{2}$, Werner Wosniok ${ }^{3}$ \\ ${ }^{1}$ Laboratório de Biologia Pesqueira - Manejo dos Recursos Aquáticos (UFPA), Av. Perimetral 2651, Terra Firme, \\ 66040170 Belém, Pará, Brazil \\ ${ }^{2}$ Leibniz Center for Tropical Marine Ecology (ZMT), Fahrenheitstr. 6, 28359 Bremen, Germany \\ ${ }^{3}$ Institute of Statistics, University of Bremen, Am Fallturm 1, 28359 Bremen, Germany
}

\begin{abstract}
Tidal migrations of fishes are influenced by several coincident factors (abiotic and biotic). The interactive effect of these multiple factors has never been analyzed statistically in a model approach. We used proportional hazards analysis to analyze the interactive effect of space (4 creeks) and time (diurnal neap tide cycles in 2 seasons) on patterns in the intertidal migration of 3 size classes of the banded puffer fish Colomesus psittacus (Tetraodontidae) from mangrove creeks and link this to ontogenetic and temporal changes in feeding. The intertidal migration strategy and patterns of vertical resource exploitation changed ontogenetically, thereby reducing intraspecific competition. Juvenile fish entered creeks earlier and left later, which resulted in longer feeding times and fuller intestines than adults. Juveniles fed mainly on barnacles and fiddler crabs from the mid-intertidal, while adults were specialized predators of the mangrove crab Ucides cordatus from the high intertidal. The shape of the migration curves (the proportions of fish leaving a creek at a given ebb tide water level) indicated that the tidal migration took place in close response to creek-specific drainage characteristics and suggests that the fish interact successfully with variable and dynamic creek features in a macrotidal mangrove environment. When ebb tide cycles were completed during daylight hours, the tidal migration was well-structured. When ebb tide overlapped with sunset, juveniles left earlier, and the tidal migration was compressed. We provide a time budget scenario of habitat use by diurnal C. psittacus during a $15 \mathrm{~d}$ spring-neap tide cycle according to the changes in interactions of flood and ebb tide with sunset and sunrise.
\end{abstract}

KEY WORDS: Ontogenetic changes · Feeding ecology · Intertidal fish migration · Fyke net • Water level · Curuçá

Resale or republication not permitted without written consent of the publisher

\section{INTRODUCTION}

The intertidal migrations of fishes are animal migrations in miniature (Gibson 2003). They connect the subtidal with the intertidal area and are important for the growth and survival of many fish species. We know the 'why' of tidal migrations for fish, namely the functions of feeding (e.g. reviews in Gibson 1982, Weisberg \& Lotrich 1982, Horn et al. 1999, Krumme 2009), predator avoidance (e.g. Ruiz et al. 1993), and reproduction
(Horn et al. 1999), but we have little knowledge about inherent patterns and processes of these migrations (the 'how'). Except for a few studies from sandy intertidal sites (e.g. Ansell \& Gibson 1990, Yamahira et al. 1996), it is largely unknown how these ecological functions are linked to temporal and spatial patterns in movement and habitat use by the fish. However, understanding the patterns in the temporary colonization of intertidal habitats by fish is crucial to understand ecological interactions, define meaningful sam- 
pling designs and provide a robust interpretation of data from tidal coasts.

The few studies that investigated patterns in intertidal distribution and habitat use of fishes in creek systems during tidal cycles found remarkable short-term patterns (e.g. Kimball \& Able 2007). Differences in intertidal appearance of species or size classes may be linked to differences in the distance between the lowwater (LW) resting site and the high-water (HW) feeding sites (Kneib 1995, Kneib \& Wagner 1994). A study in a natural US salt marsh creek revealed that tidal migrations of fishes are structured both inter- and intraspecifically (Bretsch \& Allen 2006a). Experiments conducted in a constructed pumped seawater system which was used to mimic a section of intertidal salt marsh creek showed that the non-random tidal migration pattern in prey species is influenced by the presence of their predators (Bretsch \& Allen 2006b).

Several factors, both abiotic and biotic, can influence the tidal migrations of fishes. A factor can act singly (e.g. steepness of 2 beaches; Gibson 1980) but usually 2 or more factors interact (e.g. interaction between tidal and diel cycle; e.g. Burrows et al. 1994, Laroche et al. 1997, Krumme et al. 2004). Multivariate analyses are commonly used to describe interactions among multiple factors (e.g. Laroche et al. 1997, Kimball \& Able 2007). However, the problem with such analyses is the joint effect of multiple factors on migration curves. These migration curves are distribution functions over time that need to be estimated from censored observations, and the effect that is searched for is a change of scale or shape in these curves in response to a change in values of the influencing factors. This is not the setup in which standard multivariate approaches like principal components analysis, multidimensional scaling, correspondence analysis and other dimension reducing methods operate. The appropriate approach here is to adopt methods from survival time analysis, where the target event is 'emigration' instead of 'survival'. Proportional hazards regression then allows investigation of the relation between migration curves and influencing factors, expressing effects in easily interpretable terms.

Two factors that are important in tidal fish migration behavior are feeding and predator avoidance. However, these can hardly be separated because a fish feeding on intertidal prey may automatically avoid larger predators that desist from entering shallow waters at high tide. It is therefore difficult to design field studies that allow identification of the individual contribution of each of the 2 factors.

The mangrove area in northern Brazil (second largest in the world) provides a unique setting to study the effect of multiple factors influencing a single function, namely feeding, of intertidal fish migrations. (1)
The area is characterized by semidiurnal macrotides with tidal ranges between 2 and $5 \mathrm{~m}$ that favor a clear tidal-related behavior in the fish. (2) The environmental setting is relatively simple: The subtidal sediments of the estuaries (sand, mud) are subject to intensive erosion and deposition processes, and pelagic primary production is relatively low due to high turbidity. The extensive intertidal area is characterized by muddy channel banks and large sand banks in the lower eulittoral, and a mangrove forest in the high eulittoral (only 3 tree species). The intertidal mangrove creeks connect the high intertidal zone where many fishes forage during high tides, with the subtidal areas where the fishes reside during the LW period (Krumme et al. 2004).

In the present study we assessed patterns in the intertidal migration and feeding of the banded puffer fish Colomesus psittacus (Tetraodontidae), one of the dominant intertidal fish species in mangrove creeks of Pará, northern Brazil, ranging between 19 and $52 \%$ of total catch mass (Giarrizzo \& Krumme 2008). This species allows for studying patterns in tidal fish migration while focusing on a single factor, namely feeding, because this species has virtually no natural predators due to 3 effective defense mechanisms (poisonousness due to the neurotoxin tetraodoxin; inflation with water or air; aposematism, dorsal transverse black bars as warning coloration). In addition, reproduction occurs in the subtidal (Barletta-Bergan et al. 2002) so that the species' intertidal migration is fully devoted to the function of feeding. The banded puffer is a diurnal, carnivorous, second-order consumer, and apex predator of a short neotropical mangrove food chain, preying mainly upon Cirripedia and brachyuran crabs (Krumme et al. 2007). Seasonal and size-class specific patterns in feeding are yet unknown. C. psittacus is an estuarine resident species, and all sizes can be captured in intertidal mangrove creeks. The only other abundant mangrove fish species preying on brachyuran crabs in the region is the ariid catfish Sciades herzbergii (Giarrizzo \& Saint-Paul 2008, Krumme et al. 2008).

Three interconnected field experiments were carried out. (1) Fish were sampled in short time intervals from diurnal ebb tide cycles in 4 creeks in dry and wet season months with a fyke net (Giarrizzo \& Krumme 2007). We tested the hypothesis that the migratory pattern of Colomesus psittacus was not influenced by size class, creek, season, and the time of sunset (Hypothesis 1). Unlike other approaches, which use univariate statistics to analyze the distinct number of fish present at isolated points of the tidal curve, we used proportional hazards regression to investigate the dependency of the entire migratory pattern on the instantaneous water level and additional factors jointly. (2) The 
feeding activity and the diet composition of fish from the creek with the greatest fish abundance were analyzed. We tested the hypothesis that there was no difference in feeding activity and diet composition between size classes and season (Hypothesis 2). (3) The changes in abundance distribution and feeding activity of fish caught during an entire diurnal tidal cycle were analyzed. We tested the hypothesis that there was no difference in abundance distribution and feeding activity between size classes during flood and ebb tide (Hypothesis 3).

\section{MATERIALS AND METHODS}

Study area and sampling design. The intertidal zone of the Curuçá estuary $\left(0^{\circ} 10^{\prime} \mathrm{S}, 47^{\circ} 50^{\prime} \mathrm{W}\right)$ in Pará, northern Brazil, is characterized by a complex network of dendritic creeks with a dense canopy of Rhizophora mangle and Avicennia germinans (Fig. 1). The water is turbid due to semidiurnal macrotides with a mean tidal range of $3.2 \mathrm{~m}$ at neap tides. The tide is asymmetric; flood and ebb tides last 5 and $7 \mathrm{~h}$, respectively. At neap tides, the current speeds only oscillate weakly (mean current speed: $0.2 \mathrm{~m} \mathrm{~s}^{-1}$ ) so that tidal velocity was not included in our analysis.

Samples were collected at diurnal neap tides from 4 large intertidal creeks in an estuarine zone of homogenous salinities, temperatures, $\mathrm{pH}$, Secchi depths, seston, and dissolved oxygen concentrations (Giarrizzo \& Krumme 2007). Sample months were September and November 2003 (dry season), and March and May 2004 (wet season), when salinity was 22.3, 37.5, 7.0, and 11.7, respectively. Flooded areas in Creek 1, 2, 3, and 4 were $263,336,157$, and $227 \mathrm{~m}$ long, respectively with mean areas of 9224, 4685, 2598, and $20000 \mathrm{~m}^{2}$,
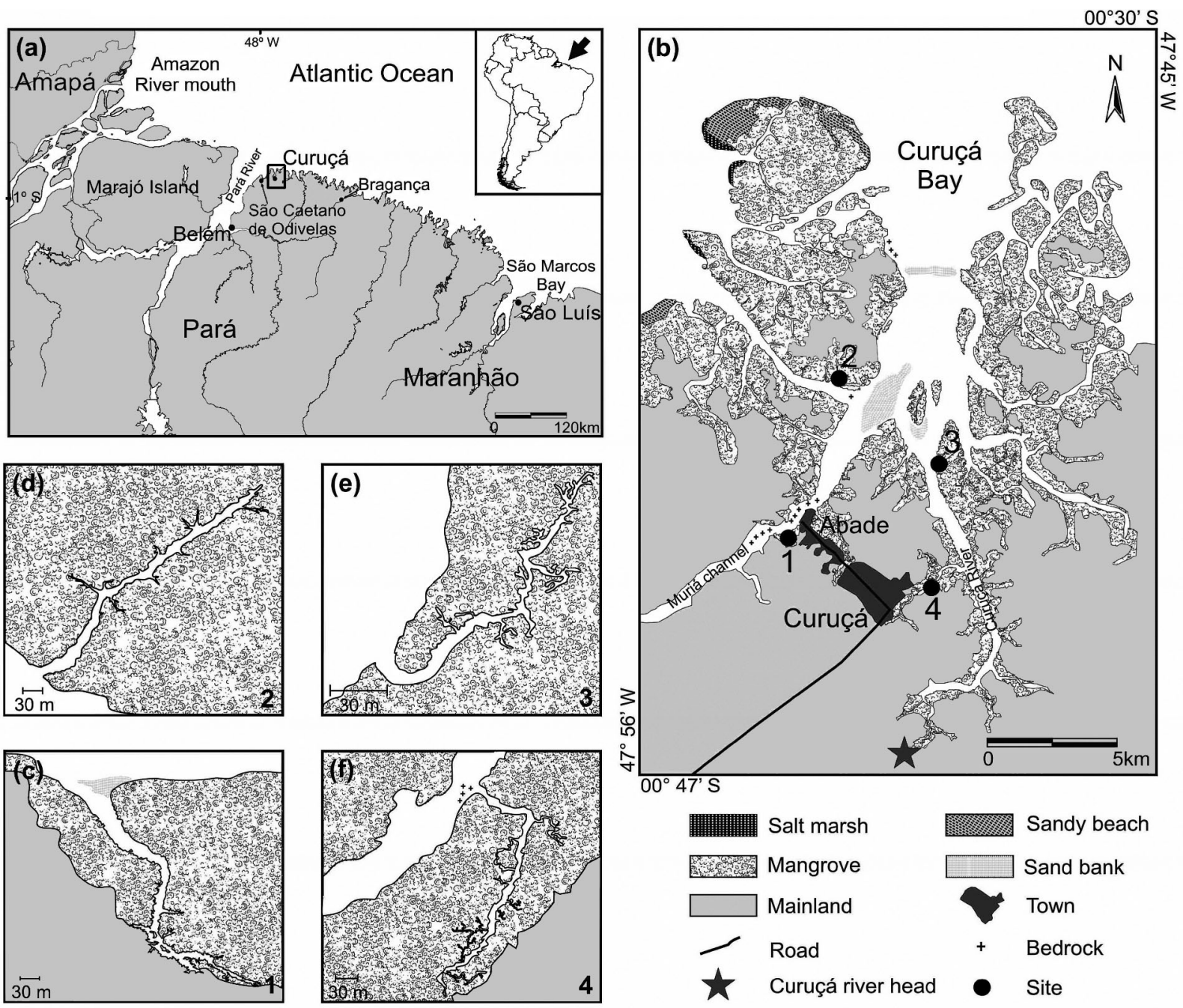
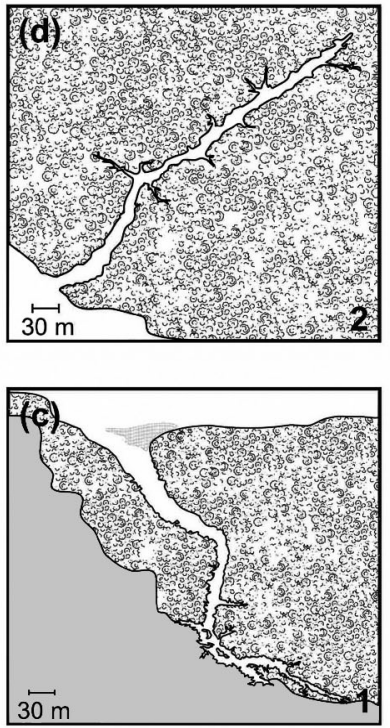
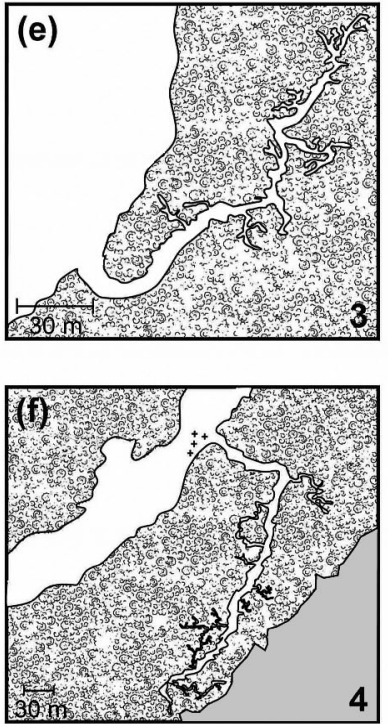

Fig. 1. (a) Coast of the states Pará and Maranhão, north Brazil, and location of the Curuçá estuary on the southern edge of the Pará River mouth; box shows study area. (b) Location of the 4 intertidal mangrove creeks (indicated by numbers 1 to 4 ) in the Curuçá estuary. (c-f) Detailed maps of the 4 creeks, ordered as shown in (b) 
respectively. The 4 creeks were all dead-ending and had no pools at the mouth and no hydrologic connection to other creek systems at neap tide.

Starting with the first day of the first quarter lunar phase, one creek was sampled each day. Due to logistic considerations, the creeks were always sampled in the series $3-4-2-1$. As a consequence, Creeks 3 and 4 de-watered fully at daytime while in Creeks 2 and 1 the ebb tide interacted with sunset.

Fish sampling and analysis. A fyke net was set at the mouth of the creeks and lifted at daytime slack HW. It consisted of 2 wings $(20 \times 6 \mathrm{~m}, 20 \mathrm{~mm}$ stretched mesh size) and a fyke net body ( 7 circular stainless-steel hoops with 100, 100, 90, 80, 80,60, $60 \mathrm{~cm}$ diameter from the outer to the inner hoop, respectively; total length: $7.5 \mathrm{~m} ; 13 \mathrm{~mm}$ stretched meshed size until the first $80 \mathrm{~cm}$ hoop, $5 \mathrm{~mm}$ from the first $80 \mathrm{~cm}$ to the innermost hoop) connected by an inlet funnel (mouth opening: $5 \mathrm{~m}$ width, $4.5 \mathrm{~m}$ height; length: $9 \mathrm{~m}$; $13 \mathrm{~mm}$ stretched meshed size) (Fig. 2). The bottom line of the wings and the inlet funnel was pushed into the mud and the headline was fixed about $1 \mathrm{~m}$ above HW level using poles of mangrove (Giarrizzo \& Krumme 2007). During ebb tide, the cod end of the fyke net was emptied and the water level measured with a ruled stake approx. every $15 \mathrm{~min}$. In macrotidal estuaries, with medium to high water currents, the fyke net is a very efficient passive sampler since the funnel of the net is less perceived as an obstacle. The successive lifting of the cod end gradually removes emigrating fish so that incidents of predatory interactions that may occur at the end of the ebb tide are reduced. A sharp rise in the

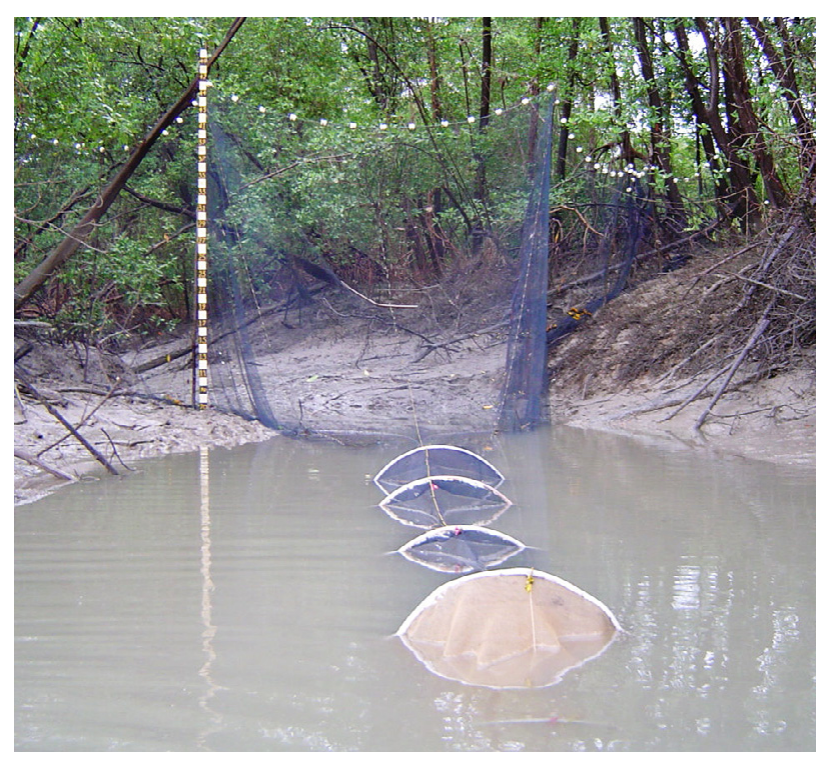

Fig. 2. Fyke net at the mouth of an intertidal creek at late ebb tide with the cod end in the downstream direction. Height of one white band on the tidal gauge: $10 \mathrm{~cm}$ number of fish in the final net clearance was detected in 7 of a total of 16 ebb cycles (Fig. 3a,b,e-i). Nearly $10 \%$ of all fish had apparently perceived the net barrier and stayed in the creek until they were ultimately forced to leave by very shallow water levels. These uncommon observations were entered into the statistical analysis as right-censored. For each size class (see class limits below), the proportion of censored individuals was not significantly different to the proportion of non-censored fish $\left(\chi^{2}=3.82, \mathrm{df}=2, \mathrm{p}=0.15\right)$. Hence, censoring did not affect the emigration pattern found. Right-censoring is the common statistical approach in this situation. It ensured that details of the fish behavior after the censoring water level did not affect modeling the emigration curve, while the fact that emigration occurred after the censoring water level was still accounted for.

The fish were kept on ice and deep-frozen in the laboratory. Colomesus psittacus were measured to $0.1 \mathrm{~cm}$ total length (TL) and wet-weighed (Sartorius PT 310, $\pm 0.01 \mathrm{~g}$ ). Fish were assigned to 3 size classes: TL < $12 \mathrm{~cm}$ (small), $12 \leq \mathrm{TL}<18 \mathrm{~cm}$ (medium), TL $\geq 18 \mathrm{~cm}$ (large). Recruitment of C. psittacus occurs continuously (Giarrizzo \& Krumme 2009) so that the gonads are small and difficult to identify (T. Giarrizzo pers. obs.), and the length at first maturity could not be identified from the specimens caught. However, assuming $19.9 \mathrm{~cm}$ TL as the length at first maturity of C. psittacus (calculated with the empirical equation from Froese \& Binohlan 2000 for a maximum TL of $32.6 \mathrm{~cm}$ using the life history tool in www.fishbase.org), the small and medium size classes basically consisted of juveniles and the large size class of adults.

To simulate a full diurnal neap tide cycle, we sampled Creek 2 on 2 consecutive days. On July 23, 2003, the ebb tide from HW to LW was sampled. On July 24, 2003, the fyke net was orientated to the incoming tide, lifted at slack LW and operated until HW. Sampling order was ebb then flood tide (separated by one nightly tidal cycle) to minimize the potential biases produced by catching the same fish migrating in and out of creeks. The net clearance proceeded as described above. The Kolmogorov-Smirnov (K-S) test was used to determine whether the abundance distribution differed among size classes at flood and ebb tide. For the remainder of this paper we call this experiment the 'tidal cycle experiment'.

Food analysis. For the food analysis, we used Colomesus psittacus caught at ebb tide from Creek 2 because more than $50 \%$ of all specimens were caught there. Only the intestinal contents were analyzed for reasons explained in Krumme et al. (2007). All but 2 specimens had filled intestines $(n=629)$. After dissection, the intestine contents of each fish were wet-weighed to the nearest $0.01 \mathrm{~g}$ (intestine content fresh weight, FW). 

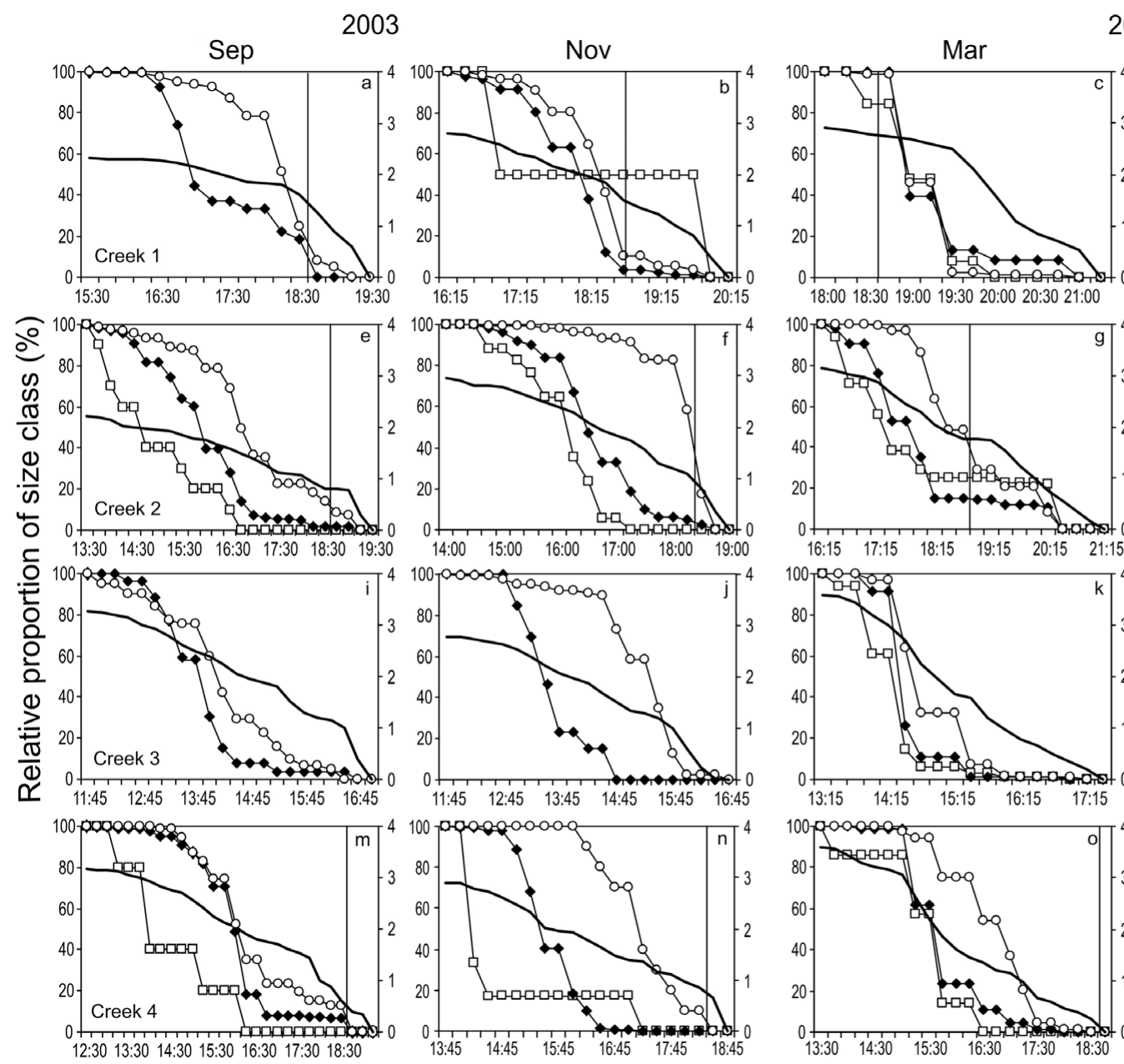

2004
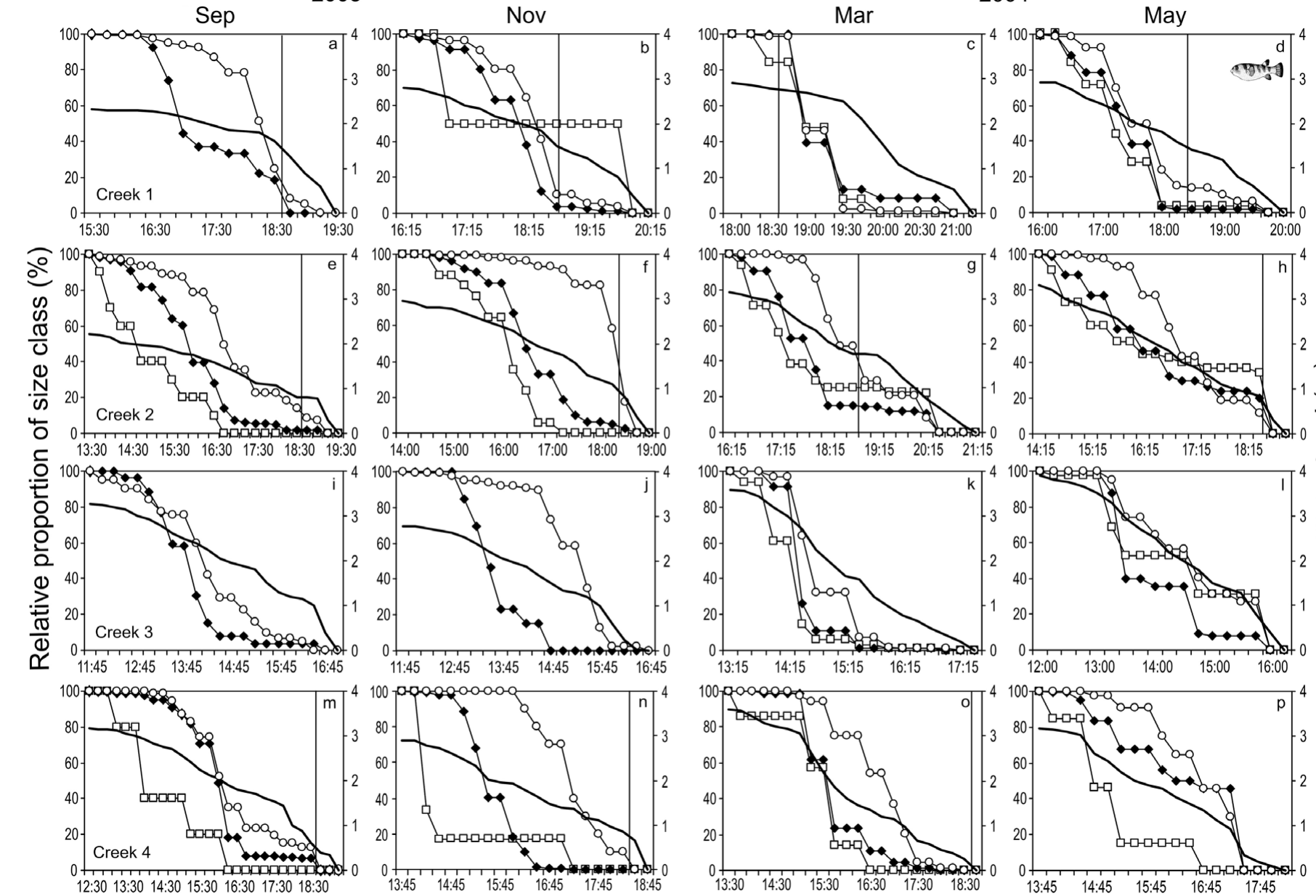

Time (h)

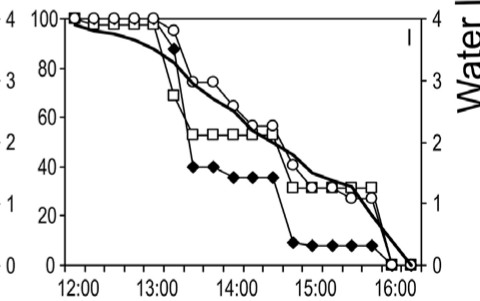

Fig. 3. Colomesus psittacus. Size-related pattern in ebb tide emigration from 4 intertidal mangrove creeks in Curuçá, Pará, north Brazil, in two 2003 dry (Sep, Nov) and two 2004 wet (Mar, May) season months. (a-d): Creek 1, (e-h): Creek 2, (i-l): Creek 3, $(\mathrm{m}-\mathrm{p})$ Creek 4 . Thick black line without symbols: water level at ebb tide. Vertical black line: time of sunset. Total number for large ( $\geq 18 \mathrm{~cm} \mathrm{TL} ; \square)$, medium (12 to $<18 \mathrm{~cm} \mathrm{TL} \diamond)$ and small $(<12 \mathrm{~cm} \mathrm{TL} ;$ O) fish given in Table 1 . Note different start times and ebb tide durations on the horizontal axes

Feeding activity. Feeding activity was expressed as intestine fullness index (IFI) which was calculated as $\mathrm{IFI}=\left(\mathrm{FW} \times \mathrm{W}^{-1}\right) \times 100$, where $\mathrm{W}$ is the fresh weight of the entire fish. Despite logarithmic transformation, ANOVA assumptions were not fulfilled. Therefore, we used the Kruskal-Wallis (K-W) test to determine whether IFI differed between size classes and between seasons, and used the Nemenyi test for post-hoc comparisons. In the analysis of the tidal cycle experiment, we used the Mann-Whitney $U$-test to determine for each size class whether the IFI differed between flood and ebb tide.

Diet composition. The intestine contents of individual fish were sorted and identified under a binocular microscope to the lowest taxon possible. Each taxon was briefly drained and then wet-weighed $( \pm 0.01 \mathrm{~g})$. For the 12 combinations of size class and month, the percentage gravimetric composition (GC) was calculated as GC $=$ (wet weight of each prey item $\times$ total wet weight of intestine contents of all specimens from the size class - month combination ${ }^{-1}$ ) $\times 100$. To assess the similarity among the 12 food content combinations, we used the Bray-Curtis similarity index in a cluster analysis (Primer 6.0, Clarke \& Warwick 1994).

Dietary overlap index. To assess the degree of intraspecific dietary overlap between the 3 size classes, the Schoener's index $(\alpha)$ was used as follows:

$$
\alpha=1-0.5 \Sigma\left|p_{X_{i}}-p_{Y_{i}}\right|
$$

where $p_{X}$ and $p_{Y}$ are the proportions by weight in intestines of the resource $i$ (prey category) for all fishsize pairs $x, y$. The index varies between 0 (no overlap) to 1 (total overlap). Dietary overlap was calculated separately for each season. 
Statistical analysis of fish migration. Intertidal fish migration is closely linked to changes in water level. Unlike other approaches, which analyze the number of fish showing a certain behavior at a certain water level, our approach focused on the direct dependency of the migratory pattern on the instantaneous water level $(L)$. The central event here is the time at which a defined migration occurs. This time may be censored, i.e. no migration takes place until the end of the observation period. For such data, the methods of survival time analysis, well known from medical statistics (Matthews \& Farewell 1988) is most appropriate. Particularly, the proportional hazards regression model is able to deal with censored data and does not require assumptions about the shape of the migration curve. The migration curves describe the proportion of fish leaving a creek at a given ebb tide water level.

The proportional hazards regression links the empirical survival distribution function $S(L)$ of the dependent quantity $L$ to the explaining factors by $S(L)=$ $\left[S_{0}(L)\right]^{\exp \left(b_{1} x_{1}+b_{2} x_{2}+\ldots\right)}$, where the $x_{i}$ are codes for factor levels and $S_{0}(L)$ is a non-parametrical baseline function, which describes the distribution of the dependent quantity when all factors are zero. The coefficients $b_{i}$ quantify the effect of the explaining factors. A nonsignificant value of $b_{i}$ indicates 'no effect of the associated factor'.

The model coefficients $b_{i}$ were estimated by the maximum likelihood method and tested for being significantly different from zero. A specific form of the survival time distribution is not involved, but the proportional hazards condition, contained in the form by which the factor $x_{i}$ acts on $S(L)$, is assumed to hold.

The use of a non-parametrical baseline distribution $S_{0}(L)$ allows accounting for creek-specific conditions in a very flexible way, while at the same time the parametrical component may have the same pattern of covariate influence over creeks. Factors were included in the model by a stepwise forward procedure using the likelihood ratio as test criterion. Statistical analyses were carried out with $\mathrm{SAS}^{\circledR}$, version 9.1.3.

Our approach considers several factors simultaneously that may influence ebb tide tidal migration patterns in the fish. Factors considered were: size class (small, medium, large), creek $(1,2,3,4)$, month (March, May, September, November), season (dry, wet), and time of day (daytime, sunset). As a dependent quantity, we alternatively used 'time after slack HW' or 'water level' at which migration occurred. We compared the performance of 'time after slack HW' versus 'water level' as dependent variables using the Akaike information criterion (AIC), which measures the goodness of fit of a model and at the same time accounts for the modeling effort in terms of the number of model parameters. This tool is appropriate here, in contrast to a formal test like the likelihood ratio test which is not possible because the models to be compared are not nested into each other. Water level performed far better in describing migration patterns (AIC using water level: 72113; AIC using time after slack HW: 72769). Therefore, water level is used as the dependent quantity in all further analyses. Similarly, the use of creek-specific distributions produced better model fits than a common baseline for all creeks; hence, all subsequent analyses are stratified by creek.

The data set showed a few uncommon rises in fish abundance at late ebb tide observations. These were methodological artifacts and therefore were treated as right-censored observations.

\section{RESULTS}

\section{Fish emigration at ebb tides}

A total of 5545 Colomesus psittacus were caught in the 4 creeks (Table 1), yielding $292 \mathrm{~kg}$ ( $54 \%$ of the total catch weight). Six species accounted for $85 \%$ of the total catch weight: C. psittacus (54\%), Sciades herzbergii (11\%), Anchovia clupeoides (7\%), Cathorops sp. (6\%), Cetengraulis edentulus ( $5 \%$ ), and Mugil curema (3\%). The overall mean $( \pm \mathrm{SD})$ C. psittacus density and biomass were 0.07 fish $\mathrm{m}^{-2}( \pm 0.06)$, and $3.35 \mathrm{~g} \mathrm{~m}^{-2}( \pm 3.22)$, respectively. Almost $70 \%$ of all C. psittacus were captured in the wet season, and $52 \%$ were caught in Creek 2. Approximately 62,29 , and $9 \%$ of the total were small, medium, and large-sized individuals, respectively. Due to higher freshwater run-off, the maximum HW levels in the creeks were on average $50 \mathrm{~cm}$ higher in the wet than in the dry season.

The ebb tide emigration of Colomesus psittacus at the creek mouths took place continuously, but generally in a consistent pattern: the larger individuals left at higher water levels (i.e. earlier) than the medium size class, which left at higher water levels than the small size class. This emigration pattern occurred irrespective of month or creek (Fig. 3). The large, medium, and small size class left at a median ebb water level of $2.29 \mathrm{~m}$ (75th and 25th percentile: 2.65 and $1.85 \mathrm{~m}), 2.1 \mathrm{~m} \mathrm{(2.32}$ and $1.94 \mathrm{~m})$, and $1.69 \mathrm{~m}$ (1.91 and $1.36 \mathrm{~m})$, respectively. In other words, size classes generally left in the order large-medium-small. The median time that the large, medium, and small size class stayed after slack HW before they left a creek was $97 \mathrm{~min}$ (75th and 25th percentile: 121 and $77 \mathrm{~min}$ ), $114 \mathrm{~min}$ (150 and $96 \mathrm{~min}$ ), and $166 \mathrm{~min}$ (190 and $151 \mathrm{~min}$ ), respectively. From the proportional hazards regression, the mean water levels at the time of creek emigration were obtained separately by fish size class (Fig. 4). Even though means varied with creek and month, the pattern large-mediumsmall was consistently maintained. 
Table 1. Colomesus psittacus. Summary of banded puffer fish catches for the 4 intertidal mangrove creeks and 4 months in Curuçá, Pará, north Brazil. WL: slack high-water level; salinity at high tide; N: total abundance of all C. psittacus caught at ebb tide; $\mathrm{N}(\% \mathrm{~N})$ : absolute and relative abundance per size class class (small: $<12 \mathrm{~cm}$ total length, TL; medium: 12 to $<18 \mathrm{~cm}$ TL; large: $\geq 18 \mathrm{~cm} \mathrm{TL}$ ); \% : relative catch weight of C. psittacus

\begin{tabular}{|c|c|c|c|c|c|c|c|c|c|}
\hline \multirow{2}{*}{ Creek } & \multirow{2}{*}{ Month } & \multirow{2}{*}{$\begin{array}{c}\text { Panel } \\
\text { in Fig. } 3\end{array}$} & \multirow{2}{*}{ WL } & \multirow{2}{*}{ Salinity } & \multirow{2}{*}{$\mathrm{N}$} & \multicolumn{3}{|c|}{$\longrightarrow \mathrm{N}(\% \mathrm{~N}) \longrightarrow$} & \multirow{2}{*}{$\% \mathrm{~W}$} \\
\hline & & & & & & Small & Medium & Large & \\
\hline 1 & Sep 03 & $\mathrm{a}$ & 2.3 & 25.4 & 152 & $125(82)$ & 27 (18) & $0(0)$ & 46 \\
\hline 1 & Nov 03 & $\mathrm{~b}$ & 2.8 & 39.6 & 139 & $56(40)$ & 81 (58) & $2(2)$ & 37 \\
\hline 1 & Mar 04 & $\mathrm{C}$ & 2.9 & 7.2 & 224 & $176(79)$ & 23 (10) & 25 (11) & 40 \\
\hline 1 & May 04 & $\mathrm{~d}$ & 2.9 & 13.3 & 165 & $80(48)$ & $60(37)$ & 25 (15) & 53 \\
\hline 2 & Sep 03 & e & 2.2 & 21.8 & 286 & $93(32)$ & $183(64)$ & $10(4)$ & 37 \\
\hline 2 & Nov 03 & $f$ & 3.0 & 40.0 & 561 & $351(63)$ & $193(34)$ & $17(3)$ & 77 \\
\hline 2 & Mar 04 & g & 3.1 & 7.3 & 646 & $356(55)$ & $162(25)$ & $128(20)$ & 67 \\
\hline 2 & May 04 & $\mathrm{~h}$ & 3.3 & 13.3 & 1366 & $989(72)$ & $268(20)$ & 109 (8) & 61 \\
\hline 3 & Sep 03 & $\mathrm{i}$ & 3.3 & 25.4 & 88 & $62(70)$ & $26(29.5)$ & $0(0)$ & 18 \\
\hline 3 & Nov 03 & $\mathrm{j}$ & 2.8 & 40.8 & 40 & $27(67)$ & $13(33)$ & $0(0)$ & 40 \\
\hline 3 & Mar 04 & $\mathrm{k}$ & 3.6 & 7.3 & 691 & $552(80)$ & $72(10)$ & $67(10)$ & 66 \\
\hline 3 & May 04 & 1 & 3.9 & 13.3 & 439 & $336(77)$ & 65 (15) & $38(9)$ & 58 \\
\hline 4 & Sep 03 & $\mathrm{~m}$ & 3.2 & 16.5 & 216 & 71 (33) & $140(65)$ & $5(2)$ & 19 \\
\hline 4 & Nov 03 & $\mathrm{n}$ & 2.9 & 29.7 & 147 & $10(7)$ & 131 (89) & $6(4)$ & 48 \\
\hline 4 & Mar 04 & o & 3.6 & 6.1 & 159 & 89 (56) & $63(40)$ & $7(4)$ & 30 \\
\hline 4 & May 04 & $\mathrm{p}$ & 3.2 & 6.8 & 226 & 87 (38) & $126(56)$ & $13(6)$ & 45 \\
\hline Total & & & & & 5545 & 3460 & 1633 & 452 & 54 \\
\hline \multicolumn{2}{|c|}{ Overall mean } & & 3.1 & 19.6 & 346.6 & $216.3(62)$ & $102.1(29)$ & $28.3(9)$ & 47 \\
\hline
\end{tabular}
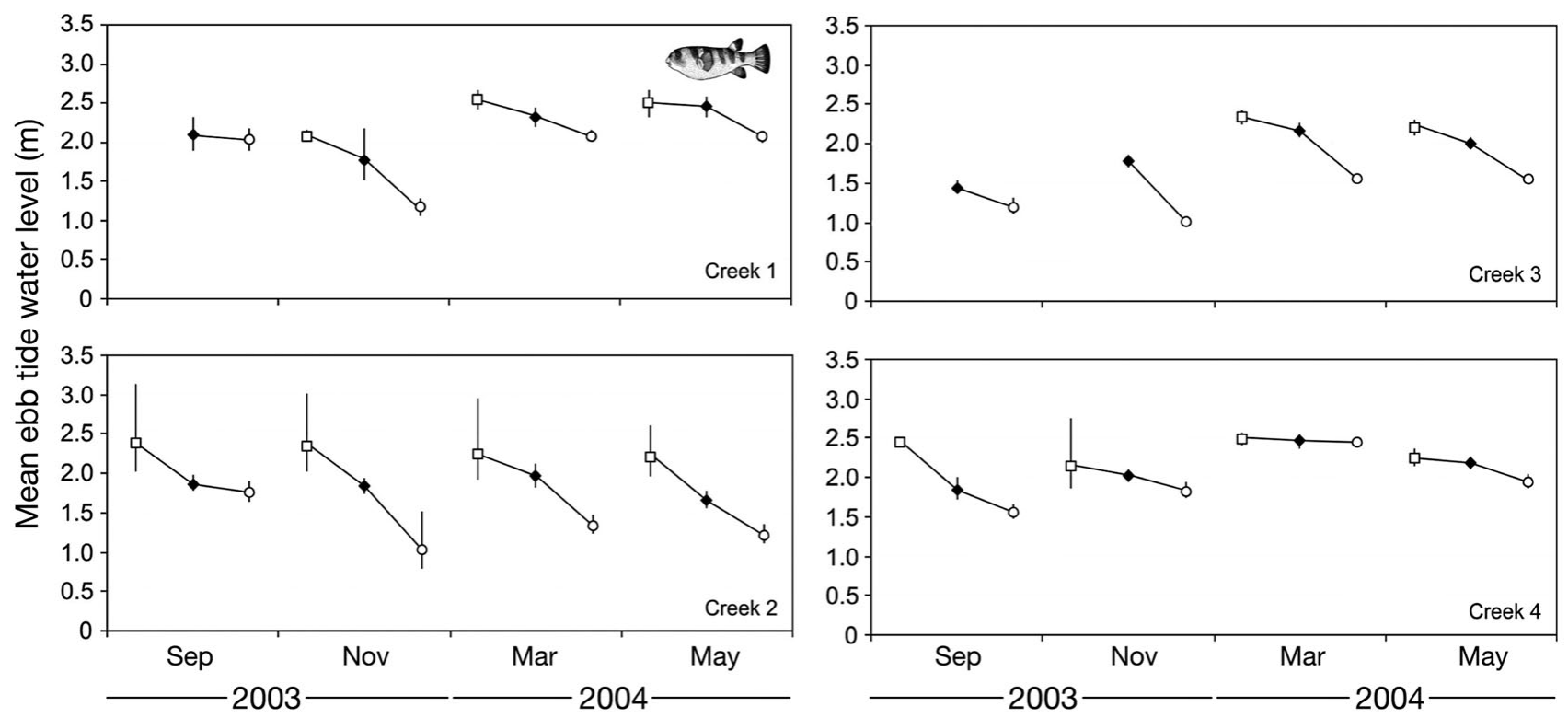

Fig. 4. Colomesus psittacus. Proportional hazards regression estimates of the mean ebb tide water level when leaving the creek with $95 \%$ CI for 3 size classes ( $\geq 18 \mathrm{~cm}$ total length, TL: $\square$; 12 to $<18 \mathrm{~cm}$ TL: $;<12 \mathrm{~cm}$ TL: O) from 4 intertidal mangrove creeks in two 2003 dry and two 2004 wet season months in north Brazil

The results of the proportional hazards regression led to the rejection of Hypothesis 1. The various combinations of months and size classes affected the water levels at which Colomesus psittacus emigrated in different ways (Fig. 5). Higher coefficient values indicate a longer stay in the creek. It is obvious that the sequence large-medium-small was consistent over time within individual creeks and among all creeks, though this order- ing was not forced by the statistical model. In some ebb tide cycles, adjacent size classes were well separated with respect to water level and time; in others, this sequence was more compressed. The separation between size classes was occasionally disturbed when sunset interfered (Fig. 3b,c,d,g,h). Then, the medium and smal size class left the creek at higher water levels, i.e. earlier than expected by the stage of the ebb tide. Fig. 3b,c,d,g,h 


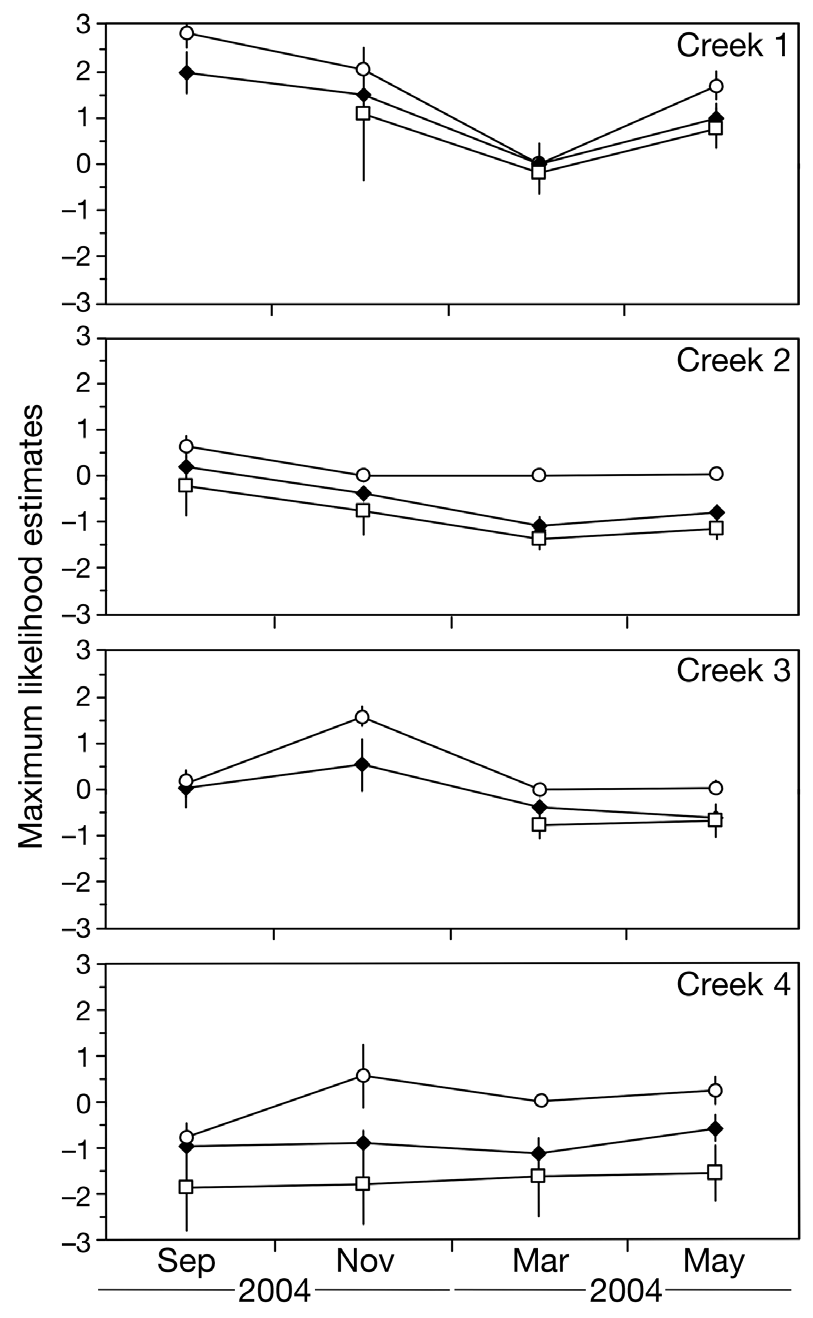

Fig. 5. Colomesus psittacus. Coefficients for the month $\times$ size class interaction, separately per creek. Coefficients of the proportional hazards regression (maximum likelihood estimates) for emigration water levels of 3 size classes (small: O; medium: $\bullet$ large: $\square$ ). Data from two 2003 dry (Sep, Nov) and two 2004 wet (Mar, May) season months; error bars indicate $\pm 2 \mathrm{SE}$

suggests that sunset prompts a premature and compressed emigration of the fish while maintaining the sequence of size classes. However, daytime and creek effect cannot be clearly separated since Creeks 1 and 2 were sampled when sunset and ebb tide overlapped, without replicates for a formal test of the sunset effect.

Months were found to have a significant influence on the emigration distribution of the fish, but the month effect was specific to each creek (likelihood ratio test, LR test, $\mathrm{p}<$ 0.0001). There was a slight tendency among small and medium fish to stay longer in the creeks in dry season months when estuarine water levels were lower (Fig. 5).

Likewise, baseline functions were found to be creekspecific (LR test, $\mathrm{p}<0.0001$ ), but migratory patterns between creeks were fairly similar. Yet, even with creek-specific baselines, no common pattern for the month $\times$ size class interaction could be found for the various creeks (LR test, $p<0.0001$ ). As an example, the large and medium fish in Creek 3 showed constant behaviour throughout the samples while they displayed clear changes in Creek 1, which in turn was different from the change in Creek 4 (Fig. 5).

\section{Tidal cycle experiment: abundance distribution}

The abundance distribution during the ebb tide of the tidal cycle experiment reflects the migration pattern displayed in the 16 ebb tide cycles, that is 'large left before medium before small' (three 2-sample K-S tests, large $>$ medium, large $>$ small, medium $>$ small, $\mathrm{p}<0.001$ ) (Fig. 6). At flood tide, the abundance distribution was reversed: the small size class entered at significantly lower water levels than the medium and large size class (two 2-sample K-S tests, p < 0.001) (rejection of Hypothesis 3). The medium and large size class did not enter at significantly different water levels (K-S test, p > 0.05). No other flood tide cycle was sampled, but the close match between the single and the 16 ebb tide cycles suggests that the flood tide cycle was representative for other flood tide cycles. Joining of the flood and ebb tide cycle showed that the median duration of stay in the intertidal creek was longest for the small (266 min), intermediate for the medium (243 min) and shortest for the large (189 min) size class.

\section{Feeding activity at ebb tide}

The null hypothesis that there was no difference in the IFI of the 3 size classes at ebb tide could be rejected

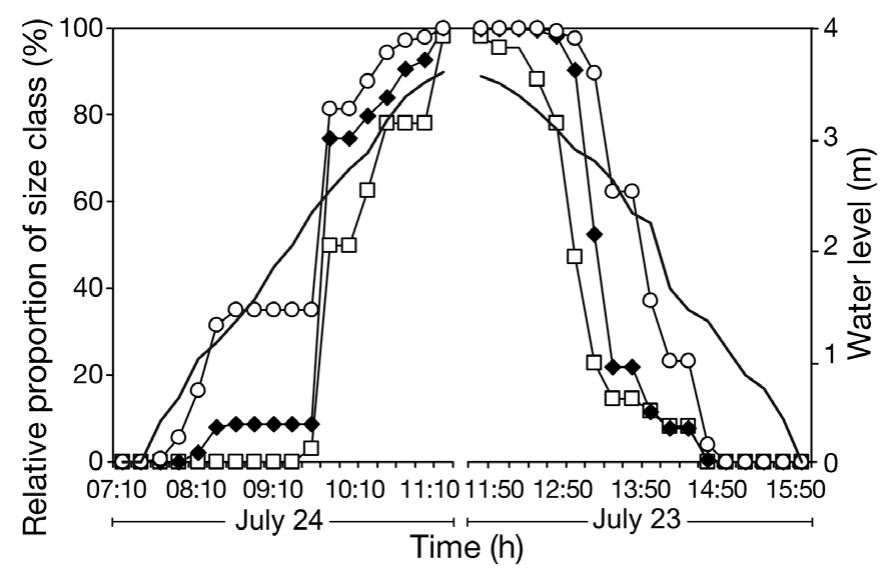

Fig. 6. Colomesus psittacus. Sequence of the relative proportion of 3 size classes (small: $O$; medium: $\bullet$, large: $\square$ ) caught with a fyke net from an intertidal mangrove creek near Curuçá, north Brazil, at flood (24 July 2003) and ebb tide (23 July 2003). Thick black lines without symbols: water level 
for the intestines analyzed from Creek 2 (rejection of Hypothesis 2). The IFI was significantly different between all possible size class combinations (K-W test, $\chi^{2}=70.934, \mathrm{df}=2, \mathrm{p}<0.001$; Nemenyi-test, $\mathrm{p}<0.01$ for large vs. medium, small; medium vs. small) (Fig. 5). The IFI of the wet season months were significantly higher than those of the dry season months (K-W test, $\chi^{2}=182.634, \mathrm{df}=3, \mathrm{p}>0.001$ ). There was no evidence for any interaction between size class and season (Fig. 7).

\section{Tidal cycle experiment: IFI}

The tidal cycle experiment revealed that the IFI of all size classes were significantly lower at flood tide (overall mean IFI: $1.4 \%$, range: 0.3 to $3.0 \%$ ) (Fig. 8) (rejection of Hypothesis 3). At ebb tide, the fish left with

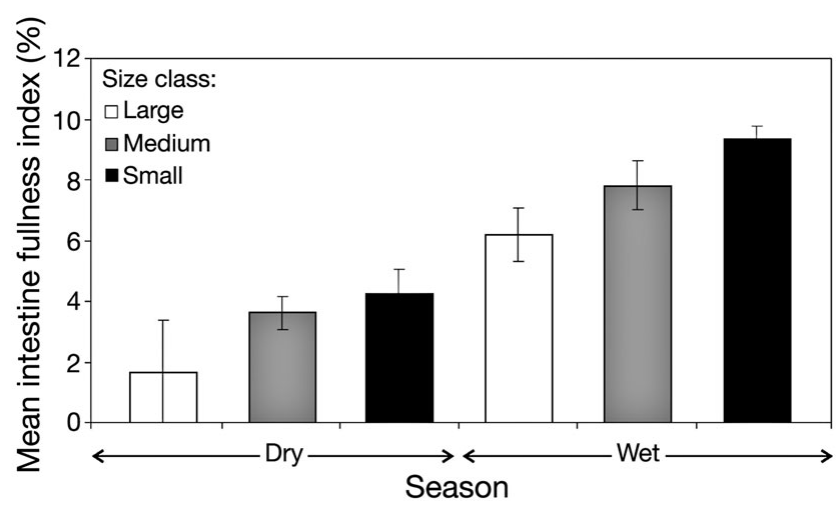

Fig. 7. Colomesus psittacus. Mean intestine fullness index with $95 \%$ CI of 3 size classes from the dry season 2003 and wet season 2004 caught in intertidal mangrove creeks near Curuçá, north Brazil

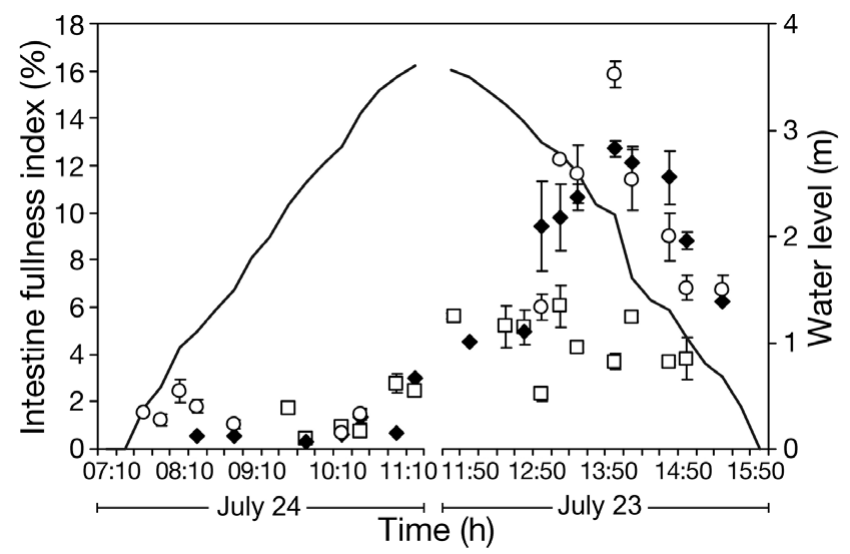

Fig. 8. Colomesus psittacus. Changes in mean intestine fullness index \pm SD of 3 size classes (large: $\square$, medium: O) of fish caught with a fyke net during a flood tide (24 July 2004, large $\mathrm{n}=1$, medium $\mathrm{n}=12$, small $\mathrm{n}=55$ ) and ebb tide (23 July 2004, large $n=27$, medium $n=40$, small $n=45$ ) from an intertidal mangrove creek near Curuçá, north Brazil. Black lines: water level filled intestines (overall mean IFI: $7.7 \%$, range: 2.0 to $15.8 \%$ ) (Mann-Whitney $U$-Test, p $<0.001$ in all 3 size classes).

\section{Patterns in diet composition}

The cluster analysis based on percentage gravimetric composition of each food item showed 3 groups with a similarity level of $48 \%$ (Fig. 9) (rejection of Hypothesis 2): Group I consisted of large Colomesus psittacus in March, May, and November. Their diet was dominated by the mangrove crab Ucides cordatus. Group II consisted of small and medium-sized specimens in the wet season months. Their diet was dominated by Cirripedia. Group III consisted of the small and medium size class in the dry season. Their diet was more diverse; important food items were Ocypodidae (mostly smaller UCa spp.), Grapsidae, other Brachyura, and Bivalvia. The classification of the large size class in September to Group III instead of Group I can be attributed to a low sample size with a vague diet composition. Bivalvia instead of $U$. cordatus accounted for $50 \%$ of their diet composition.

The Schoener index showed a great overlap (0.97) between the small and medium size class in the wet season, while there was little overlap between the large and medium size classes (0.27), and large and small size classes $(0.25)$. In the dry season, there was still considerable overlap between the small and medium size classes (0.70), and little overlap between the large and small size classes (0.28). Diet overlap between medium and large size classes was 0.54 .

\section{DISCUSSION}

The main challenge of this study was to identify patterns in tidal fish migrations. Tidal fish migration was described by the proportion of fish leaving the creek at given ebb tide water levels, where a minor part of the proportion data was censored. These migration curves were hypothesized to depend on various influencing quantities. Proportional hazards regression was used to analyze the relation between migration curves and influencing factors because this approach is constructed to model the joint effect of influencing quantities on the dependent one and to deal with a censored curve as the dependent quantity. The use of this method was successful in detecting patterns in the migration curves with respect to the order in which fish left the creeks, even though there was a considerable random and factor-induced variability in shape and scale of the various migration curves. 
(a)

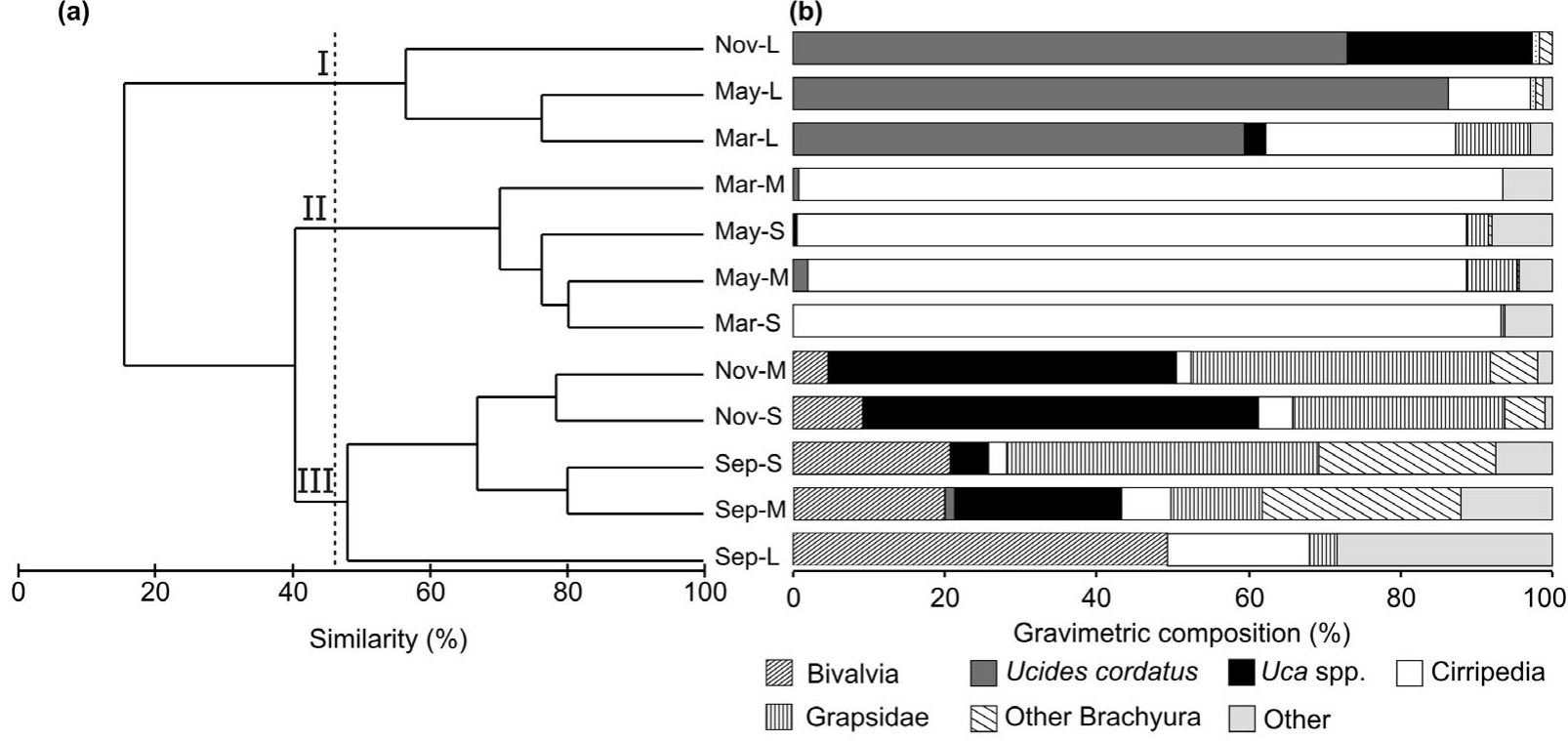

Fig. 9. Colomesus psittacus. Ordination of intestine content composition of 3 size classes (large, L: $\geq 18 \mathrm{~cm}$ total length, TL; medium, M: 12 to <18 cm TL; small, S: <12 cm TL) collected from an intertidal mangrove creek near Curuçá, north Brazil, in September and November 2003 (dry season), and March and May 2004 (wet season). (a) Cluster dendrogram. Large puffer fish in March, May, and November (Group I); small and medium puffer fish in the wet season (Group II) or the dry season (Group III). (b) Weight contribution of prey items. Diet group 'Other Brachyura' includes Xanthidae, Goneplacidae, Porcellanidae, and Portunidae

The tidal migration of a fish takes place in response to several factors. At ebb tide, we found a consistent size-structured tidal migration in the banded puffer fish Colomesus psittacus with the size group sequence large-medium-small, which was influenced by creek, month, and time of sunset (Hypothesis 1). Our study showed that the shape of the migration curves was specific for each creek, i.e. the tidal emigration was adaptive and flexible and took place in close response to creek-specific drainage characteristics (e.g. longest stay in Creek 4, which had by far the largest flooded area at neap tide). Differences in tidal migration patterns among sample sites could not result from spatial changes in abiotic parameters because our study sites were located in a zone of homogeneous water parameters (Giarrizzo \& Krumme 2007). Even though the emigration occurred over a wide range of water levels, the overall migration pattern among size classes was maintained. This highlights the site-specific adaptability of the tidal migration of fishes, which allows exploitation of a variable, though resource-rich, intertidal environment.

The factor month was an effect sui generis, which could not be substituted by an effect of season (Figs. 1 $\& 3)$. A formal test is, however, of limited use because by collapsing month to season, only one of the 2 seasons would also be influenced by a daytime effect so that a clear conclusion about the role of season cannot be obtained from the present data set.
Obviously, sunset had an effect and led to premature emigration of diurnal Colomesus psittacus, i.e. sunset had higher priority than water level when diurnal $C$. psittacus decided to emigrate. The overlap of sunset with the critical water level range of 2.65 to $1.36 \mathrm{~m}$ at ebb tide resulted in simultaneous departure of all size classes. The compressed emigration led to reduced foraging times, especially for the juvenile fish. Compressed migration patterns may generally occur when ebb or flood tide coincide with sunset or sunrise. The observed interaction between the tidal and the diel cycle suggests that the tidal migration will change between well-structured migrations (flood or ebb tide at daylight) and compressed migrations (flood or ebb tide overlap with sunrise or sunset). Due to the retardation of the tidal cycle with respect to the diel cycle (ca. $50 \mathrm{~min}$ in $24 \mathrm{~h}$ ), the length of inundations in daylight changes from day to day and is further affected by the spring-neap tide cycle.

Feeding activity and diet composition differed significantly between size classes and season (Hypothesis 2). It is remarkable that the difference in tidal migration between size classes was closely related to ontogenetic changes in IFI, diet composition, and maturity. At TL of around $18 \mathrm{~cm}$, reflecting the approximate length at first maturity, the diet shifted from grazing on sessile Cirripedia to predation on mobile crabs. The IFI is a relative value of the amount of food ingested; it was highest in the small size class and lowest in the large 
size class. Irrespective of size class, IFI was greater in the wet season, which correlated with greater HW levels, greater intertidal habitat accessibility, and lower salinities. The small and medium size classes grazed on sessile Cirripedia in the wet season, which is the peak settlement period of barnacles in the area (Marques-Silva et al. 2006). The barnacles mostly settle on the stilt roots of Rhizophora mangle, mainly located in the mid-intertidal zone (Marques-Silva et al. 2006, U. Krumme \& T. Giarrizzo pers. obs.). Feeding on Cirripedia provides small and medium-sized Colomesus psittacus with a regular food supply accessible even during neap tides, thereby fostering the growth of the juveniles. In addition, this food source does not require great predatory capacities; the barnacles are grazed off completely, and the body is ingested together with the crushed carapace (T. Giarrizzo \& U. Krumme pers. obs.). Thus, Cirripedia are a relatively heavy food item, contain a lot of carbonate, and the proportion of protein per total prey weight is likely low. The high IFI of juvenile C. psittacus likely reflects the large contribution of crushed material in the diet and the greater energy requirements per unit of body mass.

In the dry season, HW levels were lower, and the small and medium size class had a more diverse diet composed of a greater proportion of mobile epibenthic prey items from the mid-intertidal zone (Grapsidae, brachyuran crabs) (Koch 1999). Krumme et al. (2007) also observed a seasonal decrease in weight contribution of Cirripedia and an increase of brachyuran crabs in the diet of Colomesus psittacus from the Caeté estuary, Brazil, and speculated on the possible reasons. It is still unclear whether the seasonal decrease of Cirripedia in the diet of C. psittacus is related to increased natural mortality with rising salinities, or whether predation by $C$. psittacus itself reduces Cirripedia abundances after the wet season settlement peak.

The large size class was specialized on Ucides cordatus irrespective of the season. Ocypodidae exhibit a vertical zonation in the species distribution with $U$. cordatus found only on the mangrove plateau in the high intertidal (Diele et al. 2005). Intraspecific competition forces smaller $U$. cordatus to occupy the less protected edge of the mangrove plateau at lower vertical levels, where they are more susceptible to piscine predation. Given their hard carapace, the strong chelae, and agile defense behavior, their capture may require a certain ability which has to be learned. Consequently, larger and older specimens may be more capable of crushing $U$. cordatus. In terms of protein per total prey volume, the nutritional value of mobile $U$. cordatus is likely greater than that of sessile Cirripedia. The relatively late inundation and availability of the $U$. cordatus habitat is correlated with late immigration and early emigration of large Colomesus psittacus.
Interestingly, the adults entered and left the creeks at higher water levels than the juveniles, but adults must have foraged in shallower water (high intertidal) than juveniles (mid-intertidal) due to the prey items eaten. Our fyke net set at the creek mouth did not allow us to derive spatial patterns in size class distribution. However, the preference for different vertical zones does not necessary mean that the adults overtake the juveniles to forage in shallower water as suggested in Kneib \& Wagner (1994). Observations and results from test block-net samples suggest that the juveniles are distributed throughout the immersed creek systems, while the adults that arrive later are restricted to the lower reaches of the intertidal creeks, where steep edges provide access to both deeper water and the shallow high intertidal zone (U. Krumme unpubl. data).

The abundance distribution and feeding activity differed significantly between size classes during flood and ebb tide (Hypothesis 3). The size-structured tidal migration took place with the sequence smallmedium-large at flood tide and large-medium-small at ebb tide. Consequently, the duration of stay in the intertidal creeks was longest for the small size class and shortest for the large size class. The almost empty intestines throughout the flood tide suggest that the fish did not feed on their way to the intertidal creek, i.e. the subtidal area was in fact not a feeding site for Colomesus psittacus, and the species relies entirely on intertidal food sources.

We suggest a scenario for the time budget of intertidal habitat use by the diurnal banded puffer fish in north Brazilian mangrove creeks during a standard $16 \mathrm{~d}$ period (Fig. 10), which is corroborated by relative abundance changes of the species in response to the interaction of the spring-neap and diel cycle (Krumme et al. 2004).

At neap tides, when one tidal cycle occurs almost completely at daylight, the migration is well-structured among the size classes both at flood and ebb tide. Most puffer fish, however, skip the nightly HW because Ocypodidae are inactive at night (Koch 1999, Nordhaus et al. 2009).

At mid-tides prior to a spring tide, the ebb tide of the diurnal tidal cycle increasingly overlaps with sunset. The ebb tide emigration becomes compressed due to overlap with darkness. This was partially the case in our study. The nightly cycle is still unfavorable because flood tide occurs at night, and the fish are unlikely to enter against the ebb tide in the early morning.

At spring tides, when HW takes place around sunset and sunrise, the afternoon flood tide immigration and morning ebb tide emigration are well structured, while the ebb tide emigration during the early night and the flood tide immigration during the early morning are 


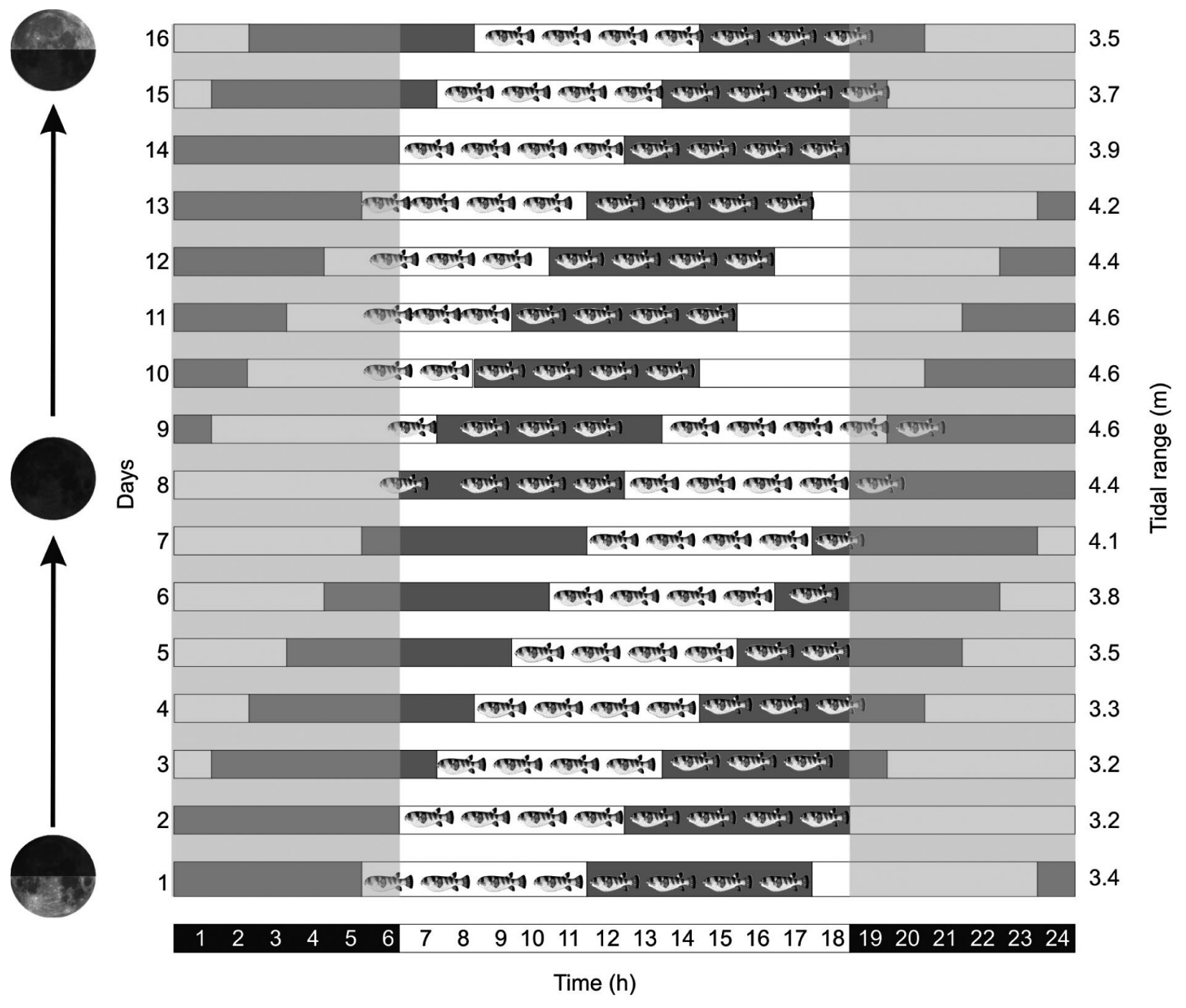

Fig. 10. Colomesus psittacus. Scenario of intertidal habitat use by the diurnal puffer fish from macrotidal mangrove creeks near Curuçá, north Brazil (semidiurnal tide) during a 16 d period (a sequence from waning, to new and to waxing moon indicated on the left). Open cells: flood tide; grey cells: ebb tide. C. psittacus icon indicates potential intertidal habitat use. Grey columns: darkness (12 h dark:12 h light cycle)

compressed. However, the fish can use the intertidal habitat each tidal cycle during approximately 4 consecutive days at maximum HW levels.

At mid-tides following a spring tide, the flood tide of the diurnal tidal cycle still overlaps with sunrise so that the morning immigration is compressed. The nightly cycle is unfavorable because flood tide occurs around sunset.

This scenario suggests 3 testable hypotheses: At spring tides (1) the foraging success of Colomesus psittacus is greater (greater IFI), (2) the fish grow faster, and (3) mortality in the intertidal prey populations is greater (see also Krumme et al. 2008). A similar temporal pattern of habitat use was found for the four-eyed fish Anableps anableps from the same man- grove region (Brenner \& Krumme 2007). Moreover, it can be assumed that at spring tides the fish have a greater food choice, both in quantity and quality. The fish can therefore feed more selectively and ingest greater food quantities, thereby minimizing intra- and interspecific competition. At neap tides, the accessibility of resources is reduced and, hence, the fish display a less selective feeding strategy, which increases the competition.

Like some salt marsh fish species (e.g. Fundulus heteroclitus), the puffer fish is important in transferring energy from intertidal mangrove to subtidal unvegetated areas. The horizontal transport of energy from highly productive intertidal vegetated habitats to poorer adjacent subtidal habitats has been described 
as a 'trophic relay' (Kneib 1997). According to our study from a tropical, macrotidal mangrove area, the energy transfer from the inter- to subtidal zone changes with the tides (neap or spring tide), time of day (day or night) and season (dry or wet). However, unlike other transient intertidal fishes which may be consumed by larger piscivores and enter a complex predator-prey food web, the poisonous puffer fish lack natural predators so that their energy transfer to the subtidal is regulated only through fish abundance, intertidal food supply, food consumption, fecal deposition, and natural and fishing mortality.

\section{CONCLUSIONS}

The intertidal migration strategy of the banded puffer fish Colomesus psittacus and patterns of vertical resource exploitation changed ontogenetically. Juveniles and adults minimized intraspecific competition by using different food sources that occur in different vertical zones in intertidal mangrove creeks. Thus, the reduction of intraspecific competition was mediated by a vertical segregation in resource use between size groups which, in turn, was linked to a size-structured tidal migration with the sequence small-mediumlarge size group at flood and large-medium-small size group at ebb tide.

The successive clearance of a fyke net body provided an appropriate method to sample tidal fish migration in a relatively unaffected way. The fitting of a proportional hazards model allowed for the identification of intertidal fish migration patterns dependant on size class, and temporal and creek-specific characteristics.

Our results show that the tidal migration of Colomesus psittacus was not random but structured by fish size. The temporal delay among size classes was linked to the exploitation of intertidal resources from different vertical zones, thereby reducing intra-specific competition (Kramer et al. 1997).

Approximately $75 \%$ of the intertidal fish in the macrotidal Pará mangroves are benthivores (Giarrizzo \& Krumme 2008). If we translate our size class pattern into an interspecific pattern of intertidal habitat use, it is likely that there is a strong assemblage organization in space and time to reduce inter- and intraspecific competition.

The size-related migration pattern of Colomesus psittacus also has implications for intertidal fish sampling adjacent to mangrove areas. Sampling with seines or gill nets in intertidal areas during the major periods of rising or falling water levels may lead to increased variation among samples because sampling is carried out when the fish are still distributing them- selves over the intertidal area. Standard surveys should therefore focus on the relatively stable periods of LW and HW.

Finally, the study highlights the creek-specific flexibility in migration patterns of intertidal fish that allows exploitation of a variable and dynamic environment. However, the tight linkage between the tide, patterns in intertidal zonation, and migration of fish also highlights the need to preserve the natural tidal regime to ensure natural patterns in resource distribution and habitat use by nektonic organisms.

Acknowledgements. The authors thank A. Jesus, E. Lameira, B. Almeida, D. Monteiro, F. Arnour, and J. Kikuchi for assistance in field collections and laboratory analyses. This work was funded by the Millennium Initiative Project 'Coastal Resources' of the Brazilian Ministry of Science and Technology. T.G. acknowledges financial support by the Fundação de Amparo à Pesquisa do Estado do Pará (FAPESPA) (Project number: 137/2008 - Universal). U.K. acknowledges financial support by the German Federal Ministry of Education and Research (BMBF). The authors thank the anonymous reviewers and the editor for constructive comments that led to an improvement of the manuscript.

\section{LITERATURE CITED}

Ansell AD, Gibson RN (1990) Patterns of feeding and movement of juvenile flatfishes on an open sandy beach. In: Barnes M, Gibson RN (eds) Trophic relationships in the marine environment. Proc 24th Eur Mar Biol Symp. Aberdeen University Press, Aberdeen, p 191-207

Barletta-Bergan A, Barletta M, Saint-Paul U (2002) Structure and seasonal dynamics of larval and juvenile fish in the mangrove-fringed estuary of the Rio Caeté in North Brazil. Estuar Coast Shelf Sci 54:193-206

> Brenner M, Krumme U (2007) Tidal migration and patterns in feeding of the four-eyed fish Anableps anableps L. in a north Brazilian mangrove. J Fish Biol 70:406-427

Bretsch K, Allen DM (2006a) Tidal migrations of nekton in salt marsh intertidal creeks. Estuar Coasts 29:479-491

$>$ Bretsch K, Allen DM (2006b) Effects of biotic factors on the depth selection of nekton. J Exp Mar Biol Ecol 334: 130-138

Burrows MT, Gibson RN, Robb L, Comely CA (1994) Temporal patterns of movement in juvenile flatfishes and their predators: underwater television observations. J Exp Mar Biol Ecol 177:251-268

Clarke KR, Warwick RM (1994) Change in marine communities: an approach to statistical analysis and interpretation. Natural Environment Research Council, Plymouth

Diele K, Koch V, Saint-Paul U (2005) Population structure, catch composition and CPUE of the artisanally harvested mangrove crab Ucides cordatus (Ocypodidae) in the Caeté estuary, North Brazil: indications for overfishing? Aquat Living Resour 18:169-178

> Froese R, Binohlan C (2000) Empirical relationships to estimate asymptotic length, length at first maturity and length at maximum yield per recruit in fishes, with a simple method to evaluate length frequency data. J Fish Biol 56: 758-773

Giarrizzo T, Krumme U (2007) Spatial differences and seasonal cyclicity in the intertidal fish fauna from four man- 
grove creeks in a salinity zone of the Curuçá Estuary, North Brazil. Bull Mar Sci 80:739-754

Giarrizzo T, Krumme U (2008) Heterogeneity in intertidal fish fauna assemblages along the world's longest mangrove area in northern Brazil. J Fish Biol 72:773-779

Giarrizzo T, Krumme U (2009) Temporal patterns in the occurrence of selected tropical fish to mangrove creeks: implication for the fisheries management in north Brazil. Braz Arch Biol Technol 52:679-687

Giarrizzo T, Saint-Paul U (2008) Ontogenetic and seasonal shifts in the diet of the pemecou sea catfish Sciades herzbergii (Siluriformes: Ariidae), from a macrotidal mangrove creek in the Curuçá estuary, Northern Brazil. Rev Biol Trop 56:861-873

Gibson RN (1980) A quantitative description of the behaviour of wild juvenile plaice (Pleuronectes platessa L.). Anim Behav 28:1202-1216

Gibson RN (1982) Recent studies on the biology of intertidal fishes. Oceanogr Mar Biol Annu Rev 20:367-414

Gibson RN (2003) Go with the flow: tidal migration in marine animals. Hydrobiologia 503:153-161

Horn MH, Martin KL, Chokowski MA (1999) Intertidal fishes: life in two worlds. Academic Press, San Diego, CA

Kimball ME, Able WA (2007) Nekton utilization of intertidal salt marsh creeks: tidal influences in natural Spartina, invasive Phragmites, and marshes treated for Phragmites removal. J Exp Mar Biol Ecol 346:87-101

Kneib RT (1995) Behaviour separates potential and realized effects of decapod crustaceans in salt marsh communities. J Exp Mar Biol Ecol 193:239-256

Kneib RT (1997) The role of tidal marshes in the ecology of estuarine nekton. Oceanogr Mar Biol Annu Rev 35: $163-220$

Kneib RT, Wagner SL (1994) Nekton use of vegetated marsh habitats at different stages of tidal inundation. Mar Ecol Prog Ser 106:227-238

Koch V (1999) Epibenthic production and energy flow in the Caeté mangrove estuary, North Brazil. PhD dissertation, University of Bremen

Kramer DL, Rangeley RW, Chapman LJ (1997) Habitat selection: patterns of spatial distribution from behavioural decisions. In: Godin JGJ (ed) Behavioural ecology of teleost fishes. Oxford University Press, Oxford, p 37-80

Editorial responsibility: Ivan Nagelkerken, Nijmegen, Netherlands
Krumme U (2009) Diel and tidal movements by fish and decapods linking tropical coastal ecosystems. In: Nagelkerken I (ed) Ecological connectivity among tropical coastal ecosystems. Springer, Berlin, p 271-324

> Krumme U, Saint-Paul U, Rosenthal H (2004) Tidal and diel changes in the structure of a nekton assemblage in small intertidal mangrove creeks in northern Brazil. Aquat Living Resour 17:215-229

Krumme U, Keuthen H, Saint-Paul U, Villwock W (2007) Contribution to the feeding ecology of the banded puffer fish Colomesus psittacus (Tetraodontidae) in north Brazilian mangrove creeks. Braz J Biol 67:383-392

> Krumme U, Brenner M, Saint-Paul U (2008) Spring-neap cycle as a major driver of temporal variations in feeding of intertidal fishes: evidence from the sea catfish Sciades herzbergii (Ariidae) of equatorial west Atlantic mangrove creeks. J Exp Mar Biol Ecol 367:91-99

Laroche J, Baran E, Rasoanandrasana NB (1997) Temporal patterns in a fish assemblage of a semiarid mangrove zone in Madagascar. J Fish Biol 51:3-20

- Marques-Silva NS, Beasley CR, Paiva Gomes C, Lima Gardunho DC, Tagliaro CH, Schories D, Mehlig U (2006) Settlement dynamics of the encrusting epibenthic macrofauna in two creeks of the Caeté mangrove estuary (North Brazil). Wetlands Ecol Manag 14:67-78

Matthews DE, Farewell VT (1988) Using and understanding medical statistics, 2nd edn. Karger AG, Basel

Nordhaus I, Diele K, Wolff M (2009) Activity patterns, feeding and burrowing behaviour of the crab Ucides cordatus (Ucididae) in a high intertidal mangrove forest in North Brazil. J Exp Mar Biol Ecol 374:104-112

$>$ Ruiz GM, Hines AH, Posey MH (1993) Shallow water as a refuge habitat for fish and crustaceans in non-vegetated estuaries: an example from Chesapeake Bay. Mar Ecol Prog Ser 99:1-16

- Weisberg SB, Lotrich VA (1982) The importance of an infrequently flooded intertidal marsh surface as an energy source for the mummichog Fundulus heteroclitus: an experimental approach. Mar Biol 66:307-310

Yamahira K, Kikuchi T, Nojima S (1996) Age specific food utilization and spatial distribution of the puffer, Takifugu niphobles, over an intertidal sand flat. Environ Biol Fishes 45:311-318

Submitted: January 25, 2010; Accepted: September 30, 2010 Proofs received from author(s): November 17, 2010 